Jordan, W. M. (1961). Lancet, 2, 1146.

Laurell, C. B. (1966). Analytical Biochemistry, 15, 45.

Moses, L. E. (1969). Fournal of the American Medical Association, 208, 694.

Nilehn, J. E. (1967). Thrombosis et Diathesis Haemorrhagica, 18, 1967.

Nilsson, I. M. (1967). In Thule International Symposium on Stroke, ed. A. Engel, and T. Larsson, p. 191. Stockholm, Nordiska Bokhandeln.

Nilsson, I. M., and Isacson, S. (1973). Progress in Surgery, 11, 46.

Nilsson, I. M., and Olow, B. (1962). Thrombosis et Diathesis Haemorrhagica, 8, 297.

Nilsson, I. M., and Pandolfi, M. (1970). Thrombosis et Diathesis Haemorrhagica, Suppl. No. 40, p. 231 .

Nilsson, I. M., Blombäck, M., and von Francken, I. (1957). Acta Medica Scandinavica, 159, 35.

Nilsson, I. M. Krook, H., Sternby, N. H., Söderberg, E., and Söderström, N. (1961). Acta Medica Scandinavica, 169, 323.
Owren, P. A., and Aas, K. (1951). Scandinavian fournal of Clinical and Laboratory Investigation, 3, 201.

Pandolfi, M. (1972). European Fournal of Clinical and Biological Research, $17,254$.

Paraskevas, M., Nilsson, I. M., and Martinsson, G. (1962). Scandinavian Fournal of Clinical and Laboratory Investigation, 14, 138.

Robertson, B. (1971). Acta Chirurgica Scandinavica, Supp.1 No. 421.

Todd, A. S. (1959). Fournal of Pathology and Bacteriology, 78, 281.

Vessey, M. P., and Doll, R. (1969). British Medical fournal, 2, 651.

von Kaulla, E., and von Kaulla, K. N. (1968). American Fournal of Clinical Pathology, 48, 69.

Pathology, 48, 69.
Wolf, P. (1953). Fournal of Clinical Pathology, 6, 34.

Zuck, Th., Bergin, J. J., Raymond, J. M., and Dwyre, W. R. (1971). Surgery, Gynecology and Obstetrics, 133, 609.

\title{
Evaluation of Hyperventilation in Treatment of Head Injuries
}

\author{
H. A. CROCKARD, D. L. COPPEL, W. F. K. MORROW
}

British Medical fournal, 1973, 4, 634-640

\section{Summary}

Reduction of the partial pressure of carbon dioxide in the arterial blood by mechanical hyperventilation $\left(\mathbf{P c o}_{2}\right.$ 25-30 mm $\mathrm{Hg} ; \mathrm{Po}_{2}$ 100-150 $\mathrm{mm} \mathrm{Hg}$ ) may be beneficial in cases of severe head injury. To evaluate its efficacy and establish prognostic guidelines intracranial pressure, radiocirculograms, and cerebrospinal fluid (C.S.F.) lactate levels were studied in 31 patients. In survivors intracranial pressure fell and cerebral blood flow improved with treatment. A C.S.F. lactate greater than $55 \mathrm{mg} / 100 \mathrm{ml}$ was associated with a poor prognosis. Selection of patients was based on clinical judgement, and adults with signs of extensive brain damage were excluded. The importance of an adequate airway and resuscitation is stressed before a final decision is made. The object of treatment is to improve the quality of survival and the criteria measured may aid in the distinction between patients with a potential for good recovery and those capable only of a vegetative existence. Many associated factors as well as hypocapnia reduce intracranial pressure, and these are discussed. We believe that hyperventilation may improve some head injuries, and further study is indicated.

\section{Introduction}

Improvements in resuscitation and surgery and the development of sophisticated intensive care units have reduced the mortality after most forms of major trauma. Unfortunately similar advancement in the management of head injuries has not been evident. In these there is direct damage to cerebral tissue, with swelling of ischaemic cells and the production of some degree of cerebral oedema. Oedema reduces the blood and oxygen supply to damaged cells, the resulting ischaemia promoting further oedema which may raise the intracranial pressure

Royal Victoria Hospital, Belfast BT12 6BA, Northern Ireland

H. A. CROCKARD, M.B., F.R.C.S., Senior Neurosurgical Registrar (Present Address: Department of Neurosurgical Studies, National Hospital for Address: Department of Neurosurgical Studies,

Nervous Diseases, Queen Square, London W.C.1.)

D. L. COPPEL, M.B., F.F.A. R.C.S., Consultant Anaesthetist
W. F. MORROW, F.R.C.P., F.F.A. R.C.s., Consultant Anaesthetist to a level which impairs vital functions and leads to death. The aim of treatment is to reduce intracranial pressure, chiefly by control of cerebral oedema.

The problem of raised intracranial pressure has been approached in various ways. Cushing (1918) incised the tentorium to reduce the effect of uncal herniation. Ransahoff $e t$ al. (1971) performed extensive craniotomies to give the swollen brain room for expansion. Osmotic diuretics (Fay, 1923) have been advocated as a method of reducing brain bulk, and Sedzimir et al. (1955) used hypothermia in an effort to reduce the brain's metabolism. Galicich and French (1961) used corticosteroids in an effort to stabilize damaged cell membranes. There is little evidence that these methods are successful in the management of widespread brain damage.

In 1936 Wolff noted the relation between the arterial carbon dioxide tension and cerebral blood flow, and Furness in 1957 showed that during intracranial procedures a reduction in arterial carbon dioxide tension by hyperventilation improved operating conditions. Later Lundburg et al. (1959) and Lassen (1966) extended the idea to patients with cerebral oedema and raised intracranial pressure resulting from head injuries. Gordon (1971) and Rossanda (1972) have shown a decreasing morbidity and mortality with this technique.

Hyperventilation of patients with head injuries was introduced in the Royal Victoria Hospital, Belfast, in late 1970, and in an effort to assess its effects objectively certain criteria were studied. This communication indicates the value of continuous monitoring of intracranial pressure and cerebral blood flow by radiocirculography and of hyperventilation therapy in certain cases. Cerebrospinal fluid (C.S.F.) lactate levels may also be of value in assessing prognosis and the effect of hyperventilation on intracranial metabolism.

A number of pathophysiological changes can be controlled by mechanical ventilation. Denny-Brown and Russell (1941) noted the loss of protective laryngeal reflexes when concussion occurred. Brackett (1971) showed generalized patchy areas of atelectasis which could be due to the accumulation of bronchial secretions or aspiration of stomach contents into the lungs. It is not difficult to appreciate how this may compromise a relatively minor head injury (fig. 1). Other forms of lung damage which may produce ventilation perfusion inequality include direct chest injury, blast or fume damage, fat embolism syndrome, oxygen toxicity, and fluid overload. Shallow, spontaneous hyperventilation is common in patients with severe head injuries, resulting in reduction of partial pressures of carbon dioxide and oxygen in arterial blood. Froman (1968) and Brown (1971) showed impaired ventilation perfusion ratios with in- 

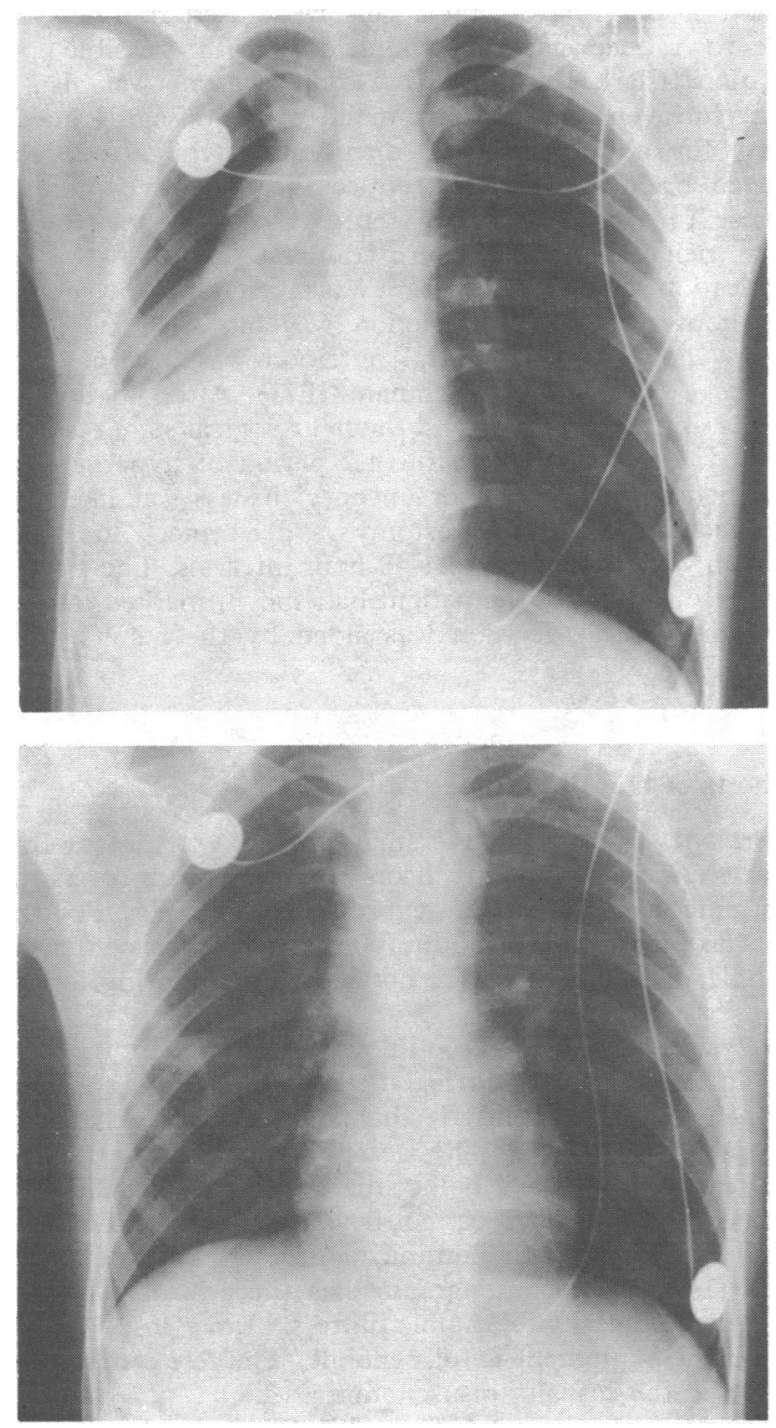

FIG. 1-Case of minor head injury. Level of consciousness im$\mathrm{X}$-ray views before (top) and after (bottom) physiotherapy and
end low endotracheal toilet. creased respiratory activity producing low $\mathrm{PCO}_{2}$ levels without improvement in $\mathrm{Po}_{2}$. In addition inefficient spontaneous respiratory effort results in increased oxygen consumption of up to $15 \%$ without any definite benefit to the patient (Bendixen et al., 1965). Controlled ventilation should alleviate the respiratory disturbances produced by any of these mechanisms.

Acute brain injury not only abolishes neuronal function but also causes tissue acidosis, oedema, and often a state of vasomotor paralysis. In undamaged areas the blood vessels can alter their calibre in response to changes in blood pressure and $\mathrm{PCO}_{\mathbf{2}}$. Blood vessels in and around a damaged area of brain, however, are maximally dilated owing to local conditions and cannot respond to other stimuli. The capacitance vessels dilate and there is an increase in intracranial blood volume (Smith et al., 1969). As this occurs in a closed cavity it follows that minor variations in intracranial volume will result in large changes in intracranial pressure (Langfitt et al., 1966). It is not uncommon to see a patient with a closed head injury deteriorate rapidly and fatally after a bout of coughing or mild respiratory obstruction. Hunter (1960) drew attention to the importance of increased abdominal muscle tone as a factor in raising central venous pressure in unconscious patients and stressed the value of muscle relaxants and controlled ventilation in reducing intracranial pressure during neurosurgical procedures. Brown (1959) and Schettini et al. (1967) attributed the reduced intracranial pressure, in part at least, to the improved venous return, reduction of central venous pressure, and a syphoning of blood from the intracranial vessels. In addition the hypocapnia produced by mechanical ventilation will cause undamaged vessels to constrict, reducing the intracranial blood volume further and allowing the intracranial pressure to fall. Such an effect was noted in our case 1 (see table I, fig. 2).

The loss of autoregulation in damaged areas of the brain is well documented. Penfield (1937) described "red veins" around an epileptic focus, and Symon (1969) reproduced the effect in experimental animals. Lassen (1966) emphasized the concept of inappropriate "luxury" perfusion in an ischaemic area of brain to draw attention to the fact that the blood flow is out of all proportion to the local metabolic requirements, with little oxygen extracted for local needs. Any increase in blood $\mathrm{CO}_{2}$ levels will dilate vessels in normal brain tissue and produce a local increase in flow with a consequent undesirable "shunt" of blood away from the damaged areas. Alexander and Lassen (1970) postulated that the converse of this also occurs, where the "shunt" or "steal" might be reversed and provide better

TABLE I-Clinical Course of Patients involved in Road-traffic Accidents before and after Hyperventilation

\begin{tabular}{|c|c|c|c|c|c|c|c|c|c|c|c|c|c|c|}
\hline \multirow{3}{*}{$\begin{array}{l}\text { Case } \\
\text { No. }\end{array}$} & \multirow{3}{*}{$\begin{array}{c}\text { Patient's } \\
\text { Age } \\
\text { (Years) }\end{array}$} & \multirow{3}{*}{ Injury } & \multicolumn{2}{|c|}{ Initial Condition } & \multirow{3}{*}{$\begin{array}{c}\text { Period } \\
\text { of Venti- } \\
\text { lation } \\
\text { (Days) }\end{array}$} & \multirow{2}{*}{\multicolumn{2}{|c|}{\begin{tabular}{|c|}
$\begin{array}{c}\text { Radiocirculo- } \\
\text { graphy } \\
\text { Transit Time } \\
\text { (sec) }\end{array}$ \\
Ventilation
\end{tabular}}} & \multirow{2}{*}{\multicolumn{2}{|c|}{$\begin{array}{c}\begin{array}{c}\text { Intra- } \\
\text { cranial } \\
\text { Pressure } \\
\text { (mm Hg) }\end{array} \\
\text { Ventilation }\end{array}$}} & \multirow{3}{*}{$\begin{array}{c}\text { Lactate } \\
\mathrm{mg} / \\
100 \mathrm{ml}\end{array}$} & \multicolumn{4}{|c|}{ Postventilation Condition } \\
\hline & & & \multirow{2}{*}{ Pupils } & \multirow{2}{*}{ General } & & & & & & & \multirow{2}{*}{ Pupils } & \multirow{2}{*}{$\begin{array}{c}\text { Response } \\
\text { to } \\
\text { Com- } \\
\text { mands } \\
\text { (Days) }\end{array}$} & \multirow{2}{*}{$\begin{array}{l}\text { Talked } \\
\text { (Days) }\end{array}$} & \multirow{2}{*}{ Other } \\
\hline & & & & & & Pre- & Post- & Pre- & Post- & & & & & \\
\hline 1 & 19 & S.D.H., & Equal & Extensor spasms & 6 & 24 & 18 & 50 & 8 & 41 & Equal & 21 & 21 & Hemiparesis \\
\hline $\begin{array}{l}2 \\
3\end{array}$ & $\begin{array}{l}18 \\
19\end{array}$ & $\begin{array}{l}\text { Oedema } \\
\text { S.D.H., } \\
\text { oedema }\end{array}$ & $\begin{array}{l}\text { Equal } \\
\text { Equal }\end{array}$ & $\begin{array}{l}\text { Extensor spasms } \\
\text { Extensor spasms }\end{array}$ & $\begin{array}{l}\mathbf{4} \\
5\end{array}$ & $\begin{array}{l}20 \\
24\end{array}$ & $\begin{array}{l}20 \\
21\end{array}$ & $\begin{array}{l}50 \\
55\end{array}$ & $\begin{array}{l}10 \\
15\end{array}$ & $\begin{array}{l}31 \\
31\end{array}$ & $\begin{array}{l}\text { Equal } \\
\text { Equal }\end{array}$ & $\begin{array}{r}5 \\
35\end{array}$ & $\begin{array}{l}14 \\
63\end{array}$ & Extensor \\
\hline 4 & 54 & $\begin{array}{l}\text { S.D.H., } \\
\text { oedema }\end{array}$ & Unequal & Drowsy, hemiparesis & 2 & 27 & 15 & 23 & $4^{*}$ & 40 & Equal & 2 & 2 & \\
\hline $\begin{array}{l}5 \\
6\end{array}$ & $\begin{array}{l}18 \\
19\end{array}$ & $\begin{array}{l}\text { Brain-stem } \\
\text { Oedema }\end{array}$ & $\begin{array}{l}\text { Equal } \\
\text { Equal }\end{array}$ & $\begin{array}{l}\text { Decerebrate, coma } \\
\text { Decerebrate, coma }\end{array}$ & $\begin{array}{l}21 \\
2 \frac{1}{2}\end{array}$ & $\begin{array}{l}22 \\
26\end{array}$ & $\begin{array}{l}24 \\
34\end{array}$ & $\begin{array}{l}22 \\
17\end{array}$ & $\begin{array}{l}28^{*} \\
30^{*}\end{array}$ & $\begin{array}{l}43 \\
66\end{array}$ & $\begin{array}{l}\text { Equal } \\
\text { Dil. } 48\end{array}$ & & & $\begin{array}{l}\text { Died } 12 \text { wks. } \\
\text { Died }\end{array}$ \\
\hline 7 & 21 & $\begin{array}{l}\text { S.D.H., } \\
\text { oedema }\end{array}$ & Unequal & $\begin{array}{c}\text { Drowsy, extensor } \\
\text { spasms }\end{array}$ & $1 \frac{1}{2}$ & 21 & $?$ & 30 & 70 & 59 & Dil. 28 & & & Died \\
\hline 8 & 53 & S.D.H., & Unequal & Hemiparesis & 2 & 28 & $?$ & 40 & 80 & 68 & Dil. 8 & & & Died \\
\hline $\begin{array}{r}9 \\
10\end{array}$ & $\begin{array}{l}22 \\
24\end{array}$ & $\begin{array}{l}\text { Oedema } \\
\text { Depressed } \\
\text { fracture }\end{array}$ & $\begin{array}{l}\text { Unequal } \\
\text { Unequal }\end{array}$ & $\begin{array}{l}\text { Focal epilepsy } \\
\text { Coma, hemiplegia }\end{array}$ & $\begin{array}{r}3 \\
16\end{array}$ & $\begin{array}{l}16 \\
23\end{array}$ & $\begin{array}{l}18 \\
19\end{array}$ & & & 32 & $\begin{array}{l}\text { Equal } \\
\text { Equal }\end{array}$ & $\begin{array}{r}5 \\
42\end{array}$ & $\begin{array}{c}28 \\
\text { Dys }\end{array}$ & Hemiparesis \\
\hline 11 & 52 & Brain-stem & Unequal & Decerebrate, coma & 2 & 18 & 21 & $\mathbf{0}$ & $\mathbf{0}$ & & Dil. 28 & & & Died \\
\hline 12 & 7 & $\begin{array}{l}\text { Depressed } \\
\text { fracture }\end{array}$ & Unequal & Coma, hemiplegia & 4 & & & 60 & 30 & & Equal & 21 & 21 & \\
\hline $\begin{array}{l}13 \\
14\end{array}$ & $\begin{array}{r}9 \\
26\end{array}$ & $\begin{array}{l}\text { Oedema } \\
\text { S.D.H., } \\
\text { oedema }\end{array}$ & $\begin{array}{l}\text { Unequal } \\
\text { Unequal }\end{array}$ & $\begin{array}{l}\text { Extensor spasms } \\
\text { Drowsy, hemiparesis }\end{array}$ & $\mathbf{2}$ & & & $\begin{array}{l}30 \\
55\end{array}$ & $\begin{array}{l}12^{*} \\
15\end{array}$ & $\begin{array}{l}38 \\
48\end{array}$ & $\begin{array}{l}\text { Equal } \\
\text { Equal }\end{array}$ & $\begin{array}{l}2 \\
2\end{array}$ & $\begin{array}{l}4 \\
7\end{array}$ & Hemiparesis \\
\hline
\end{tabular}


utilization of oxygen for the areas most in need by hypocapnic hyperventilation.

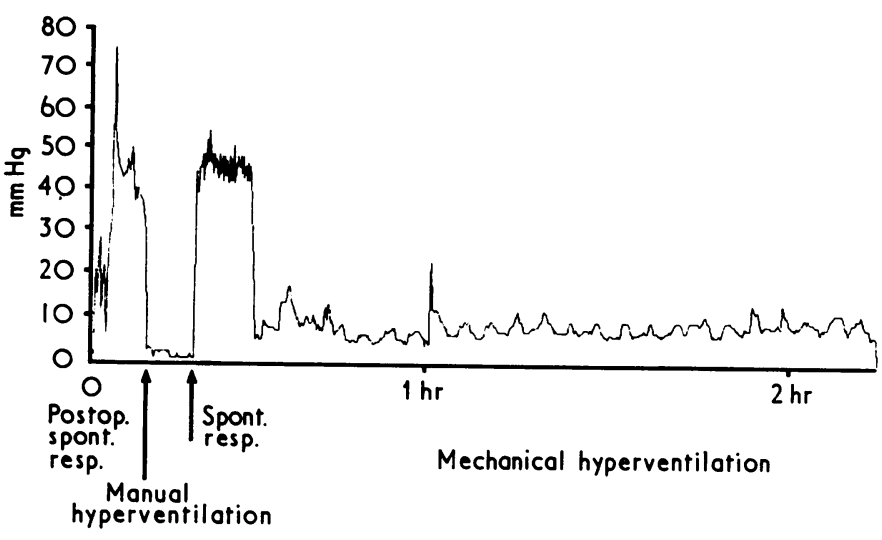

FIG. 2-Case of severe head injury with intracranial pressure $50 \mathrm{~mm} \mathrm{Hg}$ postoperatively. Rapid reduction with hyperventilation was reversed by allowing patient to breathe spontaneously. Pressure reduction was maintained by six days of hyperventilation.

Controlled ventilation facilitates tracheobronchial toilet, prevents atelectasis and aspiration, abolishes shivering, with its increase in oxygen consumption, and allows temperature to be more easily controlled. The hazards of convulsions are minimized and in addition the management of decerebrate rigidity is made easier.

Thus mechanical hyperventilation has many different and synergistic mechanisms by which it may improve the outcome after head injury. To emphasize this Rossanda (1972) preferred the term "respirator" treatment.

\section{Selection of Patients}

Resuscitation was carried out on all head-injured patients on admission, paying particular attention to the airway. Assessment of the patient's condition was made by a neurosurgeon on admission and appropriate investigations and treatment were instituted. Patients with associated chest or abdominal and/or spinal injuries were excluded from the study but not from treatment. Deliberate, unnecessary prolongation of vegetative life in those who failed to respond to resuscitation was not encouraged. In general, when there was continuation of dilated, unresponsive pupils and gross respiratory irregularities or marked decerebrate rigidity in adults active treatment was considered to be futile, but a final decision was made only after endotracheal intubation, resuscitation, and ventilation. If there was an improvement in their clinical state a trial of hyperventilation was undertaken.

The patients were admitted to a combined general respiratory and intensive care unit which is close to the neurosurgical department. On admission standard care procedures were instituted such as passage of a nasogastric tube, bladder catheterization, arterial and venous cannulation, and temperature and electrocardiographic monitoring. Routine nursing care included observation of pupillary size and reaction.

Hyperventilation was made possible by curarization with an initial dose of pancuronium bromide $(8 \mathrm{mg}$ ) and intubation with a plastic endotracheal tube (Flotex); intravenous doses of 2-4 mg of relaxant were given every half-hour. An electrically powered ventilator (Cape) with added oxygen and humidification was used and ventilation adjusted to maintain the blood carbon dioxide in the agreed range of $25-30 \mathrm{~mm} \mathrm{Hg}$ and the oxygen tension within $100-150 \mathrm{~mm} \mathrm{Hg}$. This was usually achieved with a tidal volume of $10-15 \mathrm{ml} / \mathrm{kg}$.

Diazepam and intermittent nitrous oxide overcame any problems of awareness. Volatile anaesthetics such as halothane were not used because of their tendency to increase intracranial pressure
(Jennett et al., 1969). Oral alkalis were used routinely in an effort to reduce gastric hyperacidity with possible peptic ulceration (Clark et al., 1970). Dexamethasone was also used (10 mg intravenously initially; maintenance dosage $4 \mathrm{mg}$ fourhourly) for its possible cell membrane stabilizing effect in damaged brain and also to reduce the exudative pulmonary response to aspirated gastric contents. Broad-spectrum antibiotics such as ampicillin were administered when this latter complication was suspected. Care was taken not to give excessive intravenous fluids and restriction was placed on salt intake (Gett et al., 1971). Parenteral nutrition was instituted at an early stage (Irving and Rushman, 1971). After 48 hours the patient was "decurarized" and the neurological state reassessed. If it was considered that a further period of hyperventilation would benefit the patient, or unconsciousness was likely to be prolonged, an elective tracheostomy was performed. The patients' condition was reassessed at $24-48$-hour intervals. The treatment was not considered if the patient had shown marked deterioration. This clinical decision was aided by the results of tests described below.

\section{Methods of Detailed Study}

Intracranial Pressure.-Intracranial pressure was measured with an Akers (AE830A) vented silicon beam plantar resistor type of strain gauge; pressures were expressed in $\mathrm{mm} \mathrm{Hg}$. The transducer was placed in the subdural or extradural space through a burr hole. No ill effects were noted after monitoring for up to 10 days.

Cerebral Blood Flow.-Blood flow was estimated qualitatively by radiocirculography (Taylor et al., 1972). By this technique the time taken for a radioactive bolus to pass across the cerebral blood pool is measured. The isotope (technetium-99) is introduced intravenously as a bolus; the better the flow the shorter the transit time. While it cannot be compared with the classical method of intracarotid xenon injection described by Ingvar and Lassen (1962) radiocirculography has the advantage of being atraumatic and easily repeatable up to six times in 24 hours; in addition the equipment is fully mobile. The test can be carried out even in the casualty resuscitation area.

C.S.F. Biochemistry.-C.S.F. biochemical changes were measured, paying particular attention to $\mathrm{pH}$ and lactate levels. C.S.F. was obtained by lumbar puncture after any danger from intracranial mass lesions had been excluded, and $\mathrm{pH}$ and gas levels were measured by Gordon and Rossanda's (1968) modification of Astrup's method as applied to C.S.F. Lactate and pyruvate were estimated by the enzymatic method of Gloster (1964). Full details of results in a larger series of head injuries have been published elsewhere (Crockard and Taylor, 1972).

\section{Results}

Altogether 31 patients were studied, 14 with head injuries due to road-traffic accidents (table I) and 17 with gunshot wounds of the brain (table II). Only the victims of road-traffic accidents are considered here. (Further data on the patients with gunshot wounds will be given elsewhere (Crockard, 1973); broadly, however, these showed a similar response to treatment as those described here.)

All the patients admitted after road-traffic accidents had operations. Two had extensive compound depressed fractures with severe underlying brain damage; two others presented with localizing signs but at operation there was no cerebral oedema, and at necropsy primary brain-stem haemorrhages were discovered. The remaining 10 patients had generalized oedema with or without appreciable acute subdural haematomata. All showed evidence of severe brain injury on admission, responding only to painful stimuli. Four had a marked hemiparesis and two others had extensor responses limited to one side. Extensor spasms were noted in nine patients. Many had respiratory dis- 
TABLE II-Clinical Course of Patients with Gunshot Wounds before and after Hyperventilation

\begin{tabular}{|c|c|c|c|c|c|c|c|c|c|c|c|c|c|}
\hline \multirow{3}{*}{$\begin{array}{l}\text { Case } \\
\text { No. }\end{array}$} & \multirow{3}{*}{$\begin{array}{c}\text { Patient's } \\
\text { Age } \\
\text { (Years) }\end{array}$} & \multirow{3}{*}{ Injury } & \multicolumn{2}{|c|}{ Initial Condition } & \multirow{3}{*}{$\begin{array}{l}\text { Period } \\
\text { of Vent- } \\
\text { lation } \\
\text { (Days) }\end{array}$} & \multirow{2}{*}{\multicolumn{2}{|c|}{$\begin{array}{c}\text { Radiocirculo- } \\
\text { graphy } \\
\begin{array}{c}\text { Transit Time } \\
(\mathrm{sec})\end{array} \\
\text { Ventilation }\end{array}$}} & \multirow{2}{*}{\multicolumn{2}{|c|}{$\begin{array}{c}\begin{array}{c}\text { Intra- } \\
\text { cranial } \\
\text { Pressure } \\
\text { (mm Hg) }\end{array} \\
\text { Ventilation }\end{array}$}} & \multicolumn{4}{|c|}{ Post-ventilation Condition } \\
\hline & & & \multirow{2}{*}{ Pupils } & \multirow{2}{*}{ General } & & & & & & Pupils & Response to & & Other \\
\hline & & & & & & Pre- & Post- & Pre- & Post- & opaso & (Days) & (Days) & (1) \\
\hline $\begin{array}{l}15 \\
16 \\
17 \\
18 \\
19 \\
20\end{array}$ & $\begin{array}{l}21 \\
19 \\
22 \\
24 \\
19 \\
17\end{array}$ & $\begin{array}{l}\text { Entry and exit } \\
\text { Vertex sinus } \\
\text { Entry and exit } \\
\text { Parietal } \\
\text { Parietal } \\
\text { Occipitosaggital } \\
\quad \text { sinus }\end{array}$ & $\begin{array}{l}\text { Dilated } \\
\text { Equal } \\
\text { Dilated } \\
\text { Unequal } \\
\text { Equal } \\
\text { Equal }\end{array}$ & $\begin{array}{l}\text { Coma } \\
\text { Irritable, shocked } \\
\text { Coma } \\
\text { Hemiparesis } \\
\text { Painful stimuli } \\
\text { Conscious, shocked }\end{array}$ & $\begin{array}{c}16^{\frac{1}{2}} \\
7 \\
2 \\
8 \\
6\end{array}$ & $\begin{array}{l}35 \\
38 \\
25 \\
19\end{array}$ & $\begin{array}{l}? \\
40 \\
19\end{array}$ & $\begin{array}{c}80 \\
0-60 \\
26 \\
35 \\
30-80 \\
0-50\end{array}$ & $\begin{array}{c}100 \\
20 \\
35^{*} \\
6 \\
15 \\
10\end{array}$ & $\begin{array}{l}\text { Dil. } 6 \text { hr } \\
\text { Equal } \\
\text { Dil. } \\
\text { Equal } \\
\text { Equal } \\
\text { Equal }\end{array}$ & $\begin{array}{r}21 \\
2 \\
9 \\
6\end{array}$ & $\begin{array}{r}63 \\
2 \\
6\end{array}$ & $\begin{array}{l}\text { Died } \\
\text { Died } \\
\text { Aphasic }\end{array}$ \\
\hline $\begin{array}{l}21 \\
22\end{array}$ & $\begin{array}{l}19 \\
23\end{array}$ & $\begin{array}{l}\text { Frontal } \\
\text { Occipitosaggital } \\
\text { sinus }\end{array}$ & $\begin{array}{l}\text { Dilated } \\
\text { Equal }\end{array}$ & $\begin{array}{l}\text { Coma } \\
\text { Painful stimuli }\end{array}$ & $11^{1 \frac{1}{2}}$ & & & $\begin{array}{c}0-40 \\
30\end{array}$ & 80 & $\begin{array}{l}\text { Dil. } \\
\text { Equal }\end{array}$ & 13 & & Died \\
\hline $\begin{array}{l}23 \\
24 \\
25 \\
26 \\
27 \\
28 \\
29 \\
30 \\
31\end{array}$ & $\begin{array}{l}58 \\
22 \\
24 \\
18 \\
27 \\
21 \\
23 \\
28 \\
29\end{array}$ & $\begin{array}{l}\text { Temporal } \\
\text { Occipital } \\
\text { Frontal } \\
\text { Entry and exit } \\
\text { Hemisphere } \\
\text { Temporal } \\
\text { Temporal } \\
\text { Entry and exit } \\
\text { Parietal }\end{array}$ & $\begin{array}{l}\text { Unequal } \\
\text { Dilated } \\
\text { Unequal } \\
\text { Dilated } \\
\text { Equal } \\
\text { Equal } \\
\text { Equal } \\
\text { Equal } \\
\text { Equal }\end{array}$ & $\begin{array}{l}\text { Painful stimuli } \\
\text { Coma } \\
\text { Irritable } \\
\text { Coma } \\
\text { Irritable } \\
\text { Conscious } \\
\text { Irritable } \\
\text { Irritable } \\
\text { Conscious }\end{array}$ & $\begin{array}{c}9 \\
1 \\
23 \\
{ }^{\frac{1}{2}} \\
70^{2} \\
2 \\
2 \\
2 \\
5\end{array}$ & $\begin{array}{l}18 \\
? \\
26 \\
? \\
25 \\
21 \\
30 \\
34\end{array}$ & $\begin{array}{l}? \\
? \\
21 \\
19 \\
19 \\
21 \\
?\end{array}$ & $\begin{array}{l}30 \\
30\end{array}$ & $\begin{array}{l}10 \\
10\end{array}$ & $\begin{array}{l}\text { Dil. } \\
\text { Dil. } 8 \mathrm{hr} \\
\text { Equal } \\
\text { Dil. } \\
\text { Equal } \\
\text { Equal } \\
\text { Equal } \\
\text { Dil. } 24 \mathrm{hr} \\
\text { Equal }\end{array}$ & $\begin{array}{c}8 \\
21 \\
22 \text { weeks } \\
2 \\
2 \\
5\end{array}$ & $\begin{array}{c}21 \\
26 \text { weeks } \\
2 \\
2 \\
7\end{array}$ & $\begin{array}{l}\text { Died } \\
\text { Died } \\
\text { Died }\end{array}$ \\
\hline
\end{tabular}

* Lumbar puncture pressure.

$?=$ Transit time indefinite. Dil. $6 \mathrm{hr}=$ Pupils became dilated at 6 hours.

turbances-seven showed spontaneous tachypnoea and two were hypoventilating. Nine patients had unequal pupils, three had equal pin-point pupils, and the others were normal.

After the period of mechanical hyperventilation the nine patients who ultimately survived showed improvement in their clinical condition. Three were conscious and obeyed simple commands after a period of treatment, while the remaining six took longer to recover consciousness (table I). The hemiplegia persisted in two but in the others the weakness became less in the recovery period. Of the five patients who died two deteriorated rapidly during the first 24 hours and developed dilated, unresponsive pupils and a low systemic blood pressure after a marked hypertension. The patient who had the longest period of ventilation (case 5) showed normal observations during ventilation and immediately after decurarization; however, a few hours later his respiratory pattern became disorganized and extensor spasms returned. He died three months after injury. Necropsy showed brain-stem damage.

\section{INTRACRANIAL PRESSURE}

Intracranial pressure was measured in 12 cases (table I). Initially five patients had a very high pressure $(50-60 \mathrm{~mm} \mathrm{Hg}$ ), six a moderate increase, and only one had no intracranial hypertension. In all patients who survived there was a fall in intracranial pressure by the end of the period of ventilation. Three of the five who died showed an increase of pressure during hyperventilation and one continued with a slightly raised pressure $(25-35 \mathrm{~mm} \mathrm{Hg})$; in the remaining patient the pressure was always low $(0-8 \mathrm{~mm} \mathrm{Hg})$.

There were two basic patterns of response to treatment in survivors. In three there was a rapid reduction of intracranial pressure within a few minutes of ventilation, which was easily reversed by allowing the patient to breathe spontaneously again (fig. 2) in the early post-injury period. Initially in two others there was no response to ventilation, and it was 8 and 28 hours respectively before the pressure fell. In both patients the reduction, when it occurred, was rapid (fig. 3). In one patient (case 12), while the pressure fell during ventilation it did not approach normal levels until 10 days after injury. During reassessment after 48 hours of hyperventilation in one patient (case 3) the initial pressure reduction was maintained, but in the other two patients (cases 1 and 2) there was a gradual increase in pressure with spontaneous respiration. With a further period of 48 and 72 hours of ventilation respectively their pressure remained low.

One patient (case 14) whose intracranial pressure fell developed a secondary rise $(25-30 \mathrm{~mm} \mathrm{Hg}$ ) which lasted for six hours during the period of ventilation. This was not a classic plateau wave but was similar to pressure waves noted in many of the surviving patients with bullet wounds.

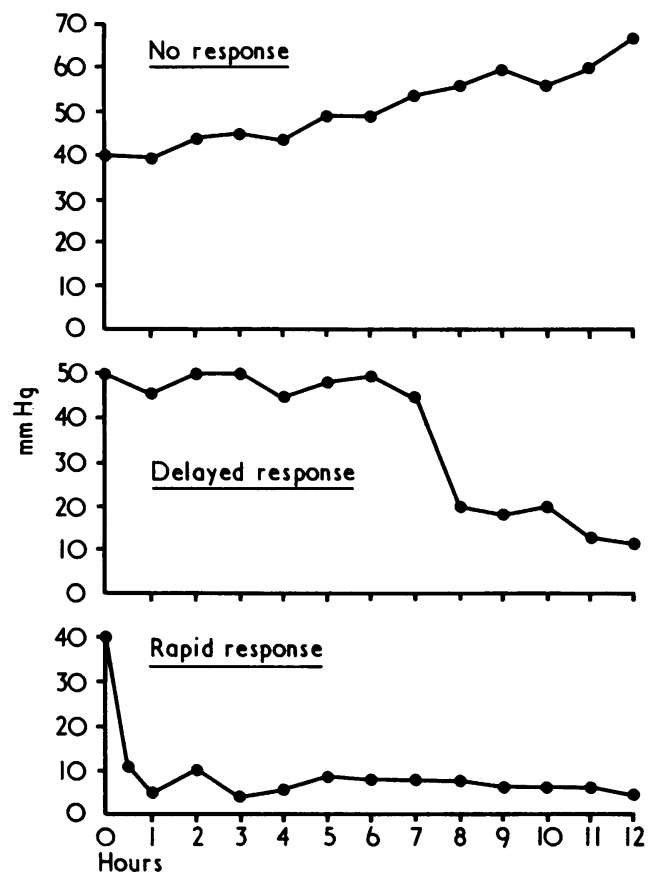

FIG. 3-Intracranial-pressure responses to hyperventilation in cases of severe head injury. Patients with reduction in pressure survived, while no response was associated with fatal outcome. There was no change in intracranial pressure or clinical state in those with normal pressure after injury.

\section{RADIOCIRCULOGRAPHY}

Eleven patients had serial radiocirculograms taken before, during, and after the period of hyperventilation. Four of the six survivors showed a decrease in transit time, in one it was unaltered, and the sixth showed a slight increase. In two with some degree of airway obstruction before treatment the transit time shortened rapidly after ventilation and remained so after decurarization (fig. 4). The other two did not show such marked reductions. In case 3 , where the transit time did not alter after four days of ventilation, there was a rapid reduction in intra- 


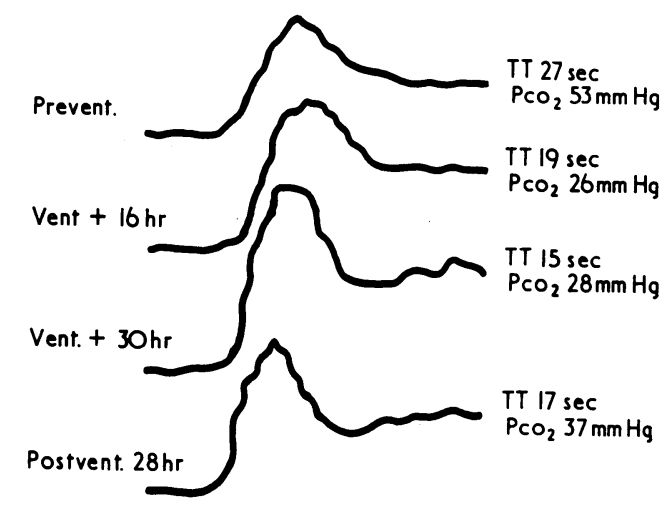

FIG. 4-Radiocirculograms obtained before, during, and after hyperventilation. Shortening of transit time (TT) occurred with reduction of $\mathrm{PCO}_{2}$, suggesting that cerebral blood flow had improved; this was maintained after treatment. (Reproduced from Progress in Brain Research, ed. J. S. Meyer and J. P. Schadé, vol. 35 , p. 279. Amsterdam, Elsevier, 1972.)

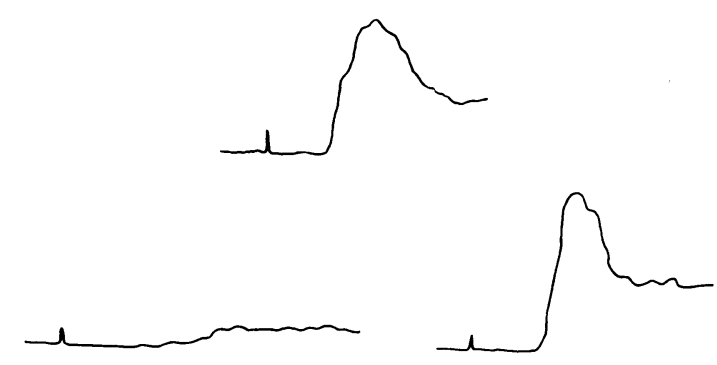

FIG. 5-Top: normal radiocirculogram. Bottom: Radiocirculograms associated with poor prognosis. Curve on bottom left suggests non-filling of intracranial vessels; curve on bottom right suggests vasoparalysis. (Reproduced from Ulster Medical fournal, 1973, 42, 52.)
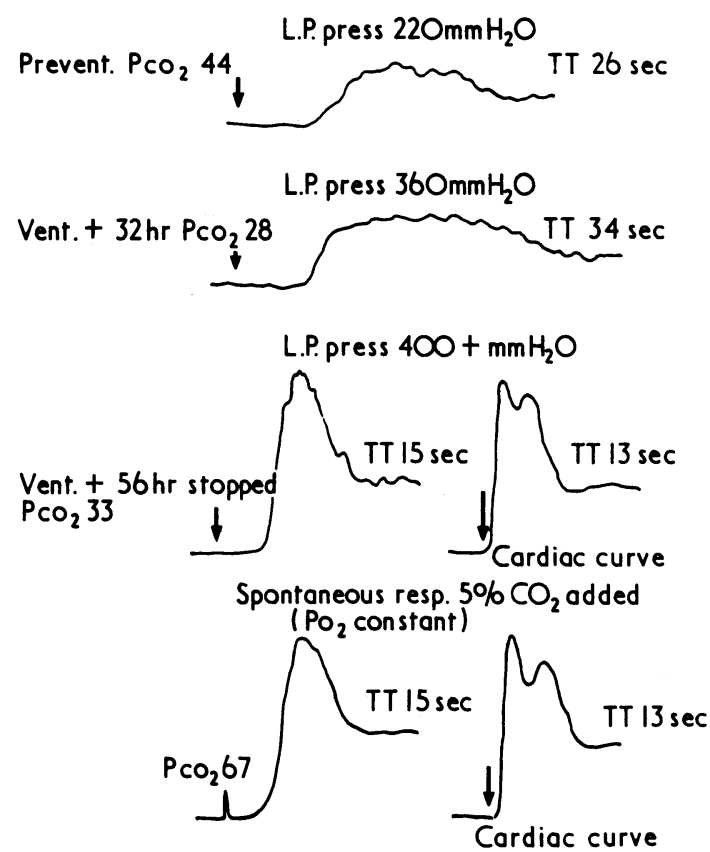

FIG. 6-Serial radiocirculograms in comatose patient with gross cerebral oedema showing increase in transit time (TT) with increasing pressure. Terminally "head" curve and "cardiac" curve became identical in shape and length, even with $\mathrm{CO}_{2}$ challenge. This suggests complete cerebral vasoparalysis. (Reproduced from Clinical Neurosurgery, 1972,
19, 129.) L.P.=Lumbar puncture.

cranial pressure. Two of the five patients who died (cases 5 and 11) showed a slight increase in transit time; the other three (cases 6,7 , and 8 ) showed a steady increase until in two (cases 7 and 8) there was no discernible curve after isotope injection (fig. 5). The other patient (case 6) showed a sudden alteration of the "head" curves, so that they became identical in shape with the "cardiac" curve (fig. 6). This curve did not alter, even when the $\mathrm{PCO}_{2}$ was deliberately increased.

\section{C.S.F. LACTATE}

Of the five patients who died three had lactate levels greater than $55 \mathrm{mg} / 100 \mathrm{ml}$. None of the survivors had such high levels. One patient whose $\mathrm{PCO}_{2}$ fell to $19 \mathrm{~mm} \mathrm{Hg}$ had a large reduction in transit time and recovered but had a persistently raised lactate which subsided only after hyperventilation had been stopped (fig. 7).

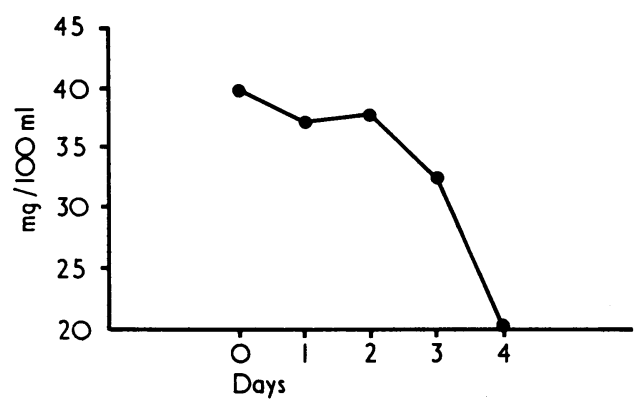

FIG. 7-Persistently raised C.S.F. lactate level during excessive hyperventilation $\left(\mathrm{PCO}_{2} 19 \mathrm{~mm} \mathrm{Hg}\right)$, suggestexcessive hyperventilation ( $\left.\mathrm{PCO}_{2} 19 \mathrm{~mm} \mathrm{Hg}\right)$, suggesting continuing anaerobic glycolysis. A $\mathrm{PCO}_{2}$
$\mathrm{~mm} \mathrm{Hg}$ must be maintained to prevent this.

\section{Discussion}

The aim of this study was to measure changes produced by hyperventilation and to attempt to correlate them with a clinical assessment of the patient's condition. This was not a controlled study, since comparable controls were not possible in the acute situation. Furthermore, it was considered unethical to withhold a form of therapy which might offer advantages to these patients. Paul et al. (1972) have shown how intracranial pressure can be influenced by altering the $\mathrm{PCO}_{2}$, and in certain patients with head injuries we have seen the deterioration in cerebral blood flow with increased $\mathrm{PCO}_{2}$. Minor degrees of respiratory obstruction have also had profound effects on intracranial pressure. Thus we felt that controlled hyperventilation was a logical form of therapy, given satisfactory methods of selecting patients. Our objective was to improve the quality of survival, not merely the prolongation of a useless existence.

It is all too easy to resuscitate a patient with a poor prognosis, to institute an indefinite period of controlled ventilation, and to produce, at best, a person capable of only a vegetative type of existence. It was our hope that certain objective criteria would help in establishing an early prognosis and also in assessing objectively the effect of ventilation.

In general we agree with Vapalahti and Troupp (1971)—“it would seem futile to attempt extensive therapy for a brain injury in a patient over 20 years of age who has Cheyne-Stokes breathing, hyperthermia, severe respiratory alkalosis and extensor rigidity-provided, of course, that these are due to brain injury and not to concomitant injuries or inadequate first aid." Unfortunately, however, it is fairly common to see patients fulfilling the above criteria who have not had adequate resuscitation, correction of acid-base imbalance, clearance of the airway, and, if necessary, re-expansion of atelectatic alveoli. It is our practice to insert an oral endotracheal tube in such patients and to control ventilation initially. If this produces a change in their clinical state with reactive pupils then mechanical hyperventilation is considered. 
There will always be patients who present problems. Two of our patients (cases 5 and 8 ) who did not respond to treatment had low C.S.F. lactate levels, and at necropsy primary brainstem damage was found. Broadly the clinical assessment carried out after 48 hours will help in deciding whether further treatment is likely to be of value. It is unlikely to be in adults if the clinical condition has deteriorated with decerebrate rigidity. Generally, however, patients who have a poor prognosis will show signs of deterioration such as dilated pupils and systemic and intracranial hypertension within 48 hours, and the decision to discontinue ventilation is made easier. This is in agreement with Rossanda's (1972) experience.

If it is thought that further clinical improvement may occur then ventilation is continued. The most striking clinical improvement was seen in those patients who required the shortest period of ventilation. The patient (case 10) who had the longest, and ultimately survived, had the greatest neurological deficit.

Monitoring of intracranial pressure was the most valuable of all the procedures for assessing prognosis and treatment. In all survivors there was a fall-in three this occurred rapidly after hyperventilation, while in two the reduction was delayed for 12 to 24 hours. The latter was explained on the basis of the experimental work of Langfitt et al. (1966) and confirms the findings of Paul et al. (1972). When brain swelling occurs after injury C.S.F. must leave the cranial compartment to allow for expansion. A moderate increase in volume at this stage will produce a very large increase in pressure. The converse is also true, hence reducing intracranial volume by a small amount will produce a sudden and marked drop in pressure. If the process causing oedema is allowed to progress further perfusion will be impaired and ischaemia will increase-a vicious circle; and systemic hypertension will be required to maintain a perfusion pressure. Ventilation at this stage will produce a change only when enough injured cells have recovered and can respond. This was assumed to be the condition of the other two survivors.

If the vicious circle continues there will be complete vasomotor paralysis and the treatment will not benefit the patient. This was the response in three of the fatal cases, where the patients showed a gradual increase in pressure until compensatory mechanisms failed. At that stage the intracranial pressure and the blood pressure fell and the pupils became unresponsive to light. Death soon followed. Thus if there is no reduction in pressure within a reasonable time the prognosis appears to be poor.

In the patients who survived there was an improvement in cerebral blood flow as judged by radiocirculography. Case 4 (fig. 5) showed a great decrease in transit time with hyperventilation, and three others showed a less marked reduction. This was interpreted as an improvement in cerebral blood flow. That two other survivors did not show the same changes may be due to other factors. Since the method depends on an intravenous injection any circulatory derangement would prolong the bolus and interfere with cerebral transit time. On the other hand, the lack of appreciable change may be due to intracranial factors, as Rossanda et al. (1972) and Bruce et al. (1972) have shown that there can be marked fluctuations in flow and vascular reactivity in the immediate post-injury period.

Of more significance prognostically were the radiocirculogram curves obtained from the patients who died. All showed an increase in transit time and in three out of five in this group a characteristically flat curve was obtained. Riishede and Ethelberg (1953) described non-filling of the intracranial vessels during angiography in fatal cases with raised intracranial pressure, and it is assumed that the flat curves on the radiocirculograms obtained from our patients were a manifestation of the same phenomenon.

The similar shape of the cardiac and head curves obtained in case 6 (fig. 7) was interpreted as evidence of complete loss of cerebrovascular control, and the lack of change with hypercapnia was taken as supportive evidence of vasoparalysis.

In a series of 38 head injuries (Crockard and Taylor, 1972) C.S.F. lactate levels were shown to correlate well with prog- nosis; only one patient survived with a level above $55 \mathrm{mg} /$ $100 \mathrm{ml}$, and all recovered with levels below $25 \mathrm{mg} / 100 \mathrm{ml}$. Three of the five who died in the present series had high levels, while none of the survivors showed such high values. As the lactic acidosis declines rapidly in C.S.F. it is important to obtain a sample within 24 hours of injury, care being taken to exclude a mass lesion before performing lumbar puncture. In the one patient whose lactate levels did not fall it was assumed that excessive hyperventilation $\left(\mathrm{PCO}_{2} 19 \mathrm{~mm} \mathrm{Hg}\right)$ was producing continuing ischaemia. Biochemical results can be obtained from the laboratory within a few hours and will aid decisions on the value of "respirator" treatment.

The mortality from head injuries unfortunately remains depressingly high. Only when preventive measures capture the imagination of the press, public, and Government can we expect to see a reduction in the numbers of patients with head injuries entering our casualty departments. A large number of lives can be saved by paying special attention to a clear airway. This preliminary report of hyperventilation therapy seems to indicate that survival prospects can be improved, but the importance of the overall care of the patient cannot be too strongly emphasized. Changing intracranial pressure, radiocirculogram, and C.S.F. lactate level are valuable indications of the efficacy of therapy and provide a guide to prognosis.

We are indebted to the nursing staffs of the respiratory and intensive care unit and the neurosurgical unit for their unfailing co-operation; to Mr. C. A. Gleadhill, Mr. D. S. Gordon, and Dr. R. C. Gray, who allowed us to study their patients; and to Professor J. W. Dundee and Mr. D. S. Gordon for their constructive criticism.

This research was supported by grants from the Royal Victoria Hospital, Belfast, and the Northern Ireland Hospitals Authority.

\section{References}

Alexander, S. C., and Lassen, N. A. (1970). Anesthesiology, 32, 60.

Bendixen, H. H., Egbert, L. D., Hedley-Whyte, J., Laver, M. B., and Pontoppidan, H. (1965). Respiratory Care. St. Louis, Mosby.

Brackett, C. E. (1971). In International Symposium on Head Injuries, p. 255. Edinburgh and London, Churchill-Livingstone.

Brown, A. S. (1959). Anaesthesia, 14, 207.

Brown, A. S. (1971). International Symposium on Head Injuries, p. 266. Edinburgh and London, Churchill-Livingstone.

Bruce, D. A., et al. (1972). European Neurology, 8, 200.

Clark, J., Watts, G., and Clarke, K. (1970). Surgery, Gynecology and Obstetrics, 130, 61

Crockard, H. A. (1973). Unpublished data.

Crockard, H. A., and Taylor, A. R. (1972). European Neurology, 8, 151.

Cushing, H. (1918). British Medical fournal, 1, 221.

Denny-Brown, D., and Russell, W. R. (1941). Brain, 64, 93.

Fay, T. (1923). Fournal of the American Medical Association, 80, 1445.

Froman, C. (1968). British Fournal of Anaesthesia, 40, 354

Furness, Diana N. (1957). British Fournal of Anaesthesia, 29, 415.

Galicich, J. H., and French, L. A. (1961). American Practitioner, 12, 169.

Gett, P. H., Jones, E. S., and Shepherd, P. (1971). British fournal of Anaesthesia, 43, 460 .

Gloster, Harris (1964). In Practical Clinical Biochemistry, ed. H. Varley, p. 516 . London, Heinemann.

p. 516. London, Heinemann.
Gordon, E. (1971). Acta Anaesthesiologica Scandinavica, 12, 51.

Gordon, E. (1971). Acta Anaesthesiologica Scandinavica, 12, 51 . 12,51 .

Hunter, A. R. (1960). Proceedings of the Royal Society of Medicine, 53, 369. Ingvar, D. H., and Lassen, N. A. (1962). Acta Physiologica Scandinavica, 54,325

Irving, M. H., and Rushman, J. B. (1971). Anaesthesia, 26, 450

Jennett, W. B., Barker, J., Fitch, W., and McDowall, D. G. (1969). Lancet, 1,61 .

Langfitt, T. W., Weinstein, J. D., and Kassel, N. F. (1966). In Head Injury Conference Proceedings, ed. W. F. Caveness and A. E. Walker, p. 172 Boston, Lippincott.

Lassen, N.A. (1966). Lancet, 2, 113.

Lundberg, L., Kjallquist, A., and Chuan Bien (1959). Acta Psychiatrica et Neurologica, Suppl. No. 34, 139.

Paul, R. L., Polanco, M. O., Turney, S. Z., McAslan, T. C., and Cowley, R. A. (1972). Fournal of Neurosurgery, 36, 714 .

Penfield, W. (1937). Association for Research in Nervous and Mental Disease Proceedings, 18, 605.

Ransahoff, J., Benjamin, M. V., Gage, E. L., and Epstein, F. (1971). Fournal

of Neurosurgery, 34, 70.
Riishede, J., and Ethelberg, S. (1953). Archives Neurology and Psychiatry 70, 399.

Rossanda, Marina (1972). Personal communication.

Rossanda, Marina, et al. (1972). European Neurology, 8, 169. 
Schettini, A., Cook, A. W., and Owre, E. S. (1967). Anesthesiology, 28, 363. Sedzimir, C. B., Jacobs, D., and Dundee, J. W. (1955). British fournal of Anaesthesia, 27, 93.

Smith, D. R., Duckert, B., and Kemp, L. G. (1969). Fournal of Neurosurgery,

Symon, L. (1969). In International Anesthesiology Clinics, No. 3, ed. D. G.
McDowall, vol. 7, p. 597. Massachusetts, Little, Brown.

Taylor, A. R., Crockard, H. A., and Bell, T. K. (1972). In Progress in Brain Research, ed. J. S. Meyer and J. P. Schadé, vol. 35, p. 283. Amsterdam, Elsevier.

Vapalahti, M., and Troupp, H. (1971). British Medical fournal, 3, 404

Wolf, H. G. (1936). Physiological Reviews, 16, 545.

\title{
Variation in Plasma Calcium with Induced Changes in Plasma Specific Gravity, Total Protein, and Albumin
}

\author{
E. M. BERRY, M. M. GUPTA, S. J. TURNER, R. R. BURNS
}

British Medical fournal, 1973, 4, 640-643

\section{Summary}

The relationship of plasma calcium levels to changes in plasma specific gravity, total protein, and albumin induced by venous stasis was investigated. Factors were derived for adjusting calcium results to offset the effects of variation in protein concentration and thus to make them of increased discriminatory value to the clinician. The validity of an existing specific gravity correction has been substantiated, but a more exact adjustment of $0.23 \mathrm{mg} / 100 \mathrm{ml}$ of calcium for every 0.001 change in specific gravity is proposed. We recommend for automated laboratories that the factor based on albumin be used: $0.09 \mathrm{mg} / 100 \mathrm{ml}$ of calcium should be subtracted from the total calcium value for every increase of $0.1 \mathrm{~g}$ in albumin above $4.6 \mathrm{~g} / 100 \mathrm{ml}$, and a corresponding addition should be made for values of albumin below $4.6 \mathrm{~g} / 100 \mathrm{ml}$.

Using a calcium specific electrode, it has been shown that the ionized calcium concentration does not alter with prolonged venous stasis.

\section{Introduction}

Calcium is present in three forms in the plasma-ionized, complexed, and protein-bound. The physiologically important fraction is the ionized calcium, but hitherto its measurement has been difficult and impracticable for a routine laboratory. Total plasma calcium is easier to determine but may not give a true index of the ionized component, because the protein-bound calcium varies independently and to a greater extent. Normally between $30 \%$ and $50 \%$ of the calcium is protein-bound (Toribara et al., 1957; Loken et al., 1960), depending on the method of determination. This proportion varies when serum protein concentration is altered as a result of disease (Prasad and Flink, 1958), change in posture (Pedersen, 1972), or prolonged venous occlusion (Philpot, 1958). At University College Hospital we have for some years used a factor based on plasma specific gravity to correct for protein variation (Philpot, 1958; Dent, 1962). The original work on which this correction was based was derived from relatively few patients, however, and has not been

\footnotetext{
Department of Clinical Pathology and Metabolic Unit, University College Hospital, London WC1E 6AU

E. M. BERRY, M.B., M.R.C.P., Registrar in Clinical Pathology (Present address: Department of Medicine B, Hadassah University Hospital P.O.B. 499, Jerusalem, Israel)

M. M. GUPTA, M.D., Research Assistant

S. J. TURNER, B.SC., Biochemist

R. R. BURNS, M.sc., Biochemist
}

published in detail (C. E. Dent, personal communication). Specific gravity varies mainly with total protein concentration but is also influenced by abnormally high sugar, urea, and lipid levels. The usual manual technique employed for its measurement is not very sensitive because a change of one unit in the third decimal place corresponds to a change in total protein of between 0.3 and $0.4 \mathrm{~g} / 100 \mathrm{ml}$ (Varley, 1967). This compares unfavourably with the precision of analyses achieved by automated procedures for the determination of serum total protein and albumin, which can be measured to within $0.1 \mathrm{~g} / 100 \mathrm{ml}$.

There is a linear relation between total calcium and total protein (Gutman and Gutman, 1937; van Leeuwen et al., 1961) and between total calcium and albumin (Moore, 1971). It follows that there must be a similar linear relation with specific gravity. We have tried here to derive and compare factors for correcting calcium results based on specific gravity, total protein, and albumin measurements.

\section{Methods}

Blood was taken from 25 healthy male doctors and medical students, aged between 21 and 35, both before and after venous stasis. The venous return was obstructed for 15 minutes by applying a sphygmomanometer cuff to the arm and maintaining a pressure of $90 \mathrm{~mm} \mathrm{Hg}$. Heparinized plasma was separated within five minutes for calcium and specific gravity estimations. Total protein and albumin were determined on serum samples.

Total calcium was measured by an E.G.T.A. (1, 2-Bis-2aminotheoxyethane-NNN'N'-tetra-acetic acid) Zincon method (Halse, 1967) with a within-batch coefficient of variation of $1.6 \%$. Specific gravity was measured by the copper sulphate method (Phillips et al., 1950). Total protein was determined by a modified biuret reaction, ${ }^{*}$ with a coefficient of variation of $1.2 \%$. Albumin was measured by a method using bromcresol green (Northam et al., 1967) with modifications to sample volume and buffer concentrations and with a coefficient of variation of $2.0 \%$. For the last two procedures purified human albumin (Behringwerke) was used for preparing the standards. In seven of the subjects ionized calcium was also measured with a calcium specific electrode (Orion calcium-selective, flow-through electrode, model $98 / 20$ ) with a coefficient of variation of $2 \cdot 8 \%$. For each subject both the specimens taken before and those taken after venous stasis were analysed in the same batch.

\section{Methods of Statistical Analysis and Results}

The change in total calcium with change in specific gravity, total protein, and albumin concentration induced by venous stasis is shown by a series of lines in figs. 1, 2, and 3. The data were analysed assuming there was a series of parallel lines which described each subject's change in calcium concentration with 